\title{
Ground-Water Contribution from the Silurian/Devonian Carbonate Aquifer to the Mad River Valley, Southwestern Ohio ${ }^{1}$
}

Rodney A. Sheet's ani) Whildam P. Yost, U.S. Geological Survey, Water Resources Division, Columbus, OH 43212

\begin{abstract}
The U.S. Geological Survey Regional Aquifer-System Analysis is examining the Silurian and Devonian carbonate aquifer and overlying glacial deposits of western Ohio and eastern Indiana in terms of the hydrogeologic framework, ground-water-flow system and water chemistry, and response to withdrawals and development. This paper describes the hydrogeology of an area in southwestern Ohio that contains the Mad River Valley, an outwash valley that is incised through the relatively permeable Silurian bedrock into the relatively impermeable Ordovician bedrock at the southern boundary of Silurian rocks. Ground-water-flow patterns based on a synoptic water-level survey of 80 bedrock wells in the Silurian and Devonian carbonate aquifer indicate that flow is toward the valley. A ground-water basin was delineated from the potentiometricsurface map and used in conjunction with a low-flow gain-loss study to derive a generalized ground-water/ surface-water budget for the area. Results of this budget indicate that ground-water recharge rates through the ground moraine to the carbonate aquifer range from 4 to $6 \mathrm{in} / \mathrm{yr}(10-15 \mathrm{~cm} / \mathrm{yr})$ and that approximately 60 to $80 \%$ of the base flow in the Mad River may ultimately consist of ground water derived from the Silurian and Devonian carbonate aquifer. Previous studies of surface- and ground-water chemistry in the area also support the conclusion that the Mad River Valley functions as a discharge area for the surrounding carbonate aquifer. Results of this study can be useful in characterizing ground-water flow and recharge rates for the Silurian and Devonian carbonate and valley aquifers along the southern boundary of this extensive regional aquifer system.
\end{abstract}

OHIO J. SCI. 94 (5): 138-146, 1994

\section{INTRODUCTION}

In 1988, the U.S. Geological Survey's Regional AquiferSystem Analysis (RASA) program began an investigation of the hydrogeologic framework, the present ground-water-flow system and water chemistry, and effects of ground-water development in the Midwestern Basin and Arches Region (Fig. 1). This RASA investigation has focused primarily on the Silurian and Devonian carbonates and surficial unconsolidated deposits of western Ohio and eastern Indiana (Bugliosi 1990). A major objective of this RASA is characterization of the aquifer system, in terms of regional ground-water-flow patterns.

A system of river valleys filled with various lacustrine, alluvial, and glacial deposits is present throughout the Silurian and Devonian carbonate aquifer system. These valleys were formed predominantly as a result of several Pleistocene continental glaciations. As the ice retreated northward, sediment-laden rivers incised the bedrock of western Ohio and eastern Indiana, creating the valleys and later depositing valley-fill material. The hydrologic characteristics of these valleys vary with the type of materials deposited in them and the depth of incision into the bedrock. In some valleys, unconsolidated deposits yield more ground water than the bedrock that they incise; in other valleys, usable ground-water resources are negligible. The hydrologic interaction of these valleys with the ground-water-flow regime of the permeable bedrock is important to the understanding of boundary conditions for the regional ground-water analysis.

Manuscript received 8 April 1994 and in revised form 12 September $1994(\# 94-07)$.

\section{Previous Investigations}

Orton (1874) and Leverett (1897) were probably among the first to describe the water-bearing potential of bedrock and unconsolidated deposits of southwestern Ohio. Fuller and Clapp (1912) wrote an overview of the area's water resources, which includes a county-bycounty description of the physiography, springs, wells, and the water-bearing potential of lithologic units. The large water-bearing potential of the river valleys in this part of Ohio has led many authors to publish waterresource information for these valleys (e.g., Norris and Spieker 1966, Norris and Eagon 1971). In contrast, few publications describe the ground-water resources of the Ordovician shale and limestone subcrops in this area, probably because of the scarcity of potable ground water, which would limit the amount of subsurface data avaitable from well drillers. In fact, most authors refer to the Ordovician bedrock as "impermeable" or "impervious" to ground-water flow (Orton 1874; Fuller and Clapp 1912; Harker and Bernhagen 1943; and Norris et al. 1947, 1949, 1952). Works that describe the Silurian and Devonian carbonate aquifer system in this area are more numerous than those that describe the Ordovician bedrock, but are less numerous than those that describe ground-water resources of the valleys.

\section{Purpose and Scope}

The purpose of this paper is to describe the hydrogeology of the Mad River Valley aquifer system in southwestern Ohio and its hydrologic relation to the surrounding Silurian and Devonian carbonate aquifer that it incises. Ground-water flow based on measured water levels in the Silurian and Devonian carbonate aquifer, stream-discharge measurements of the Mad River 


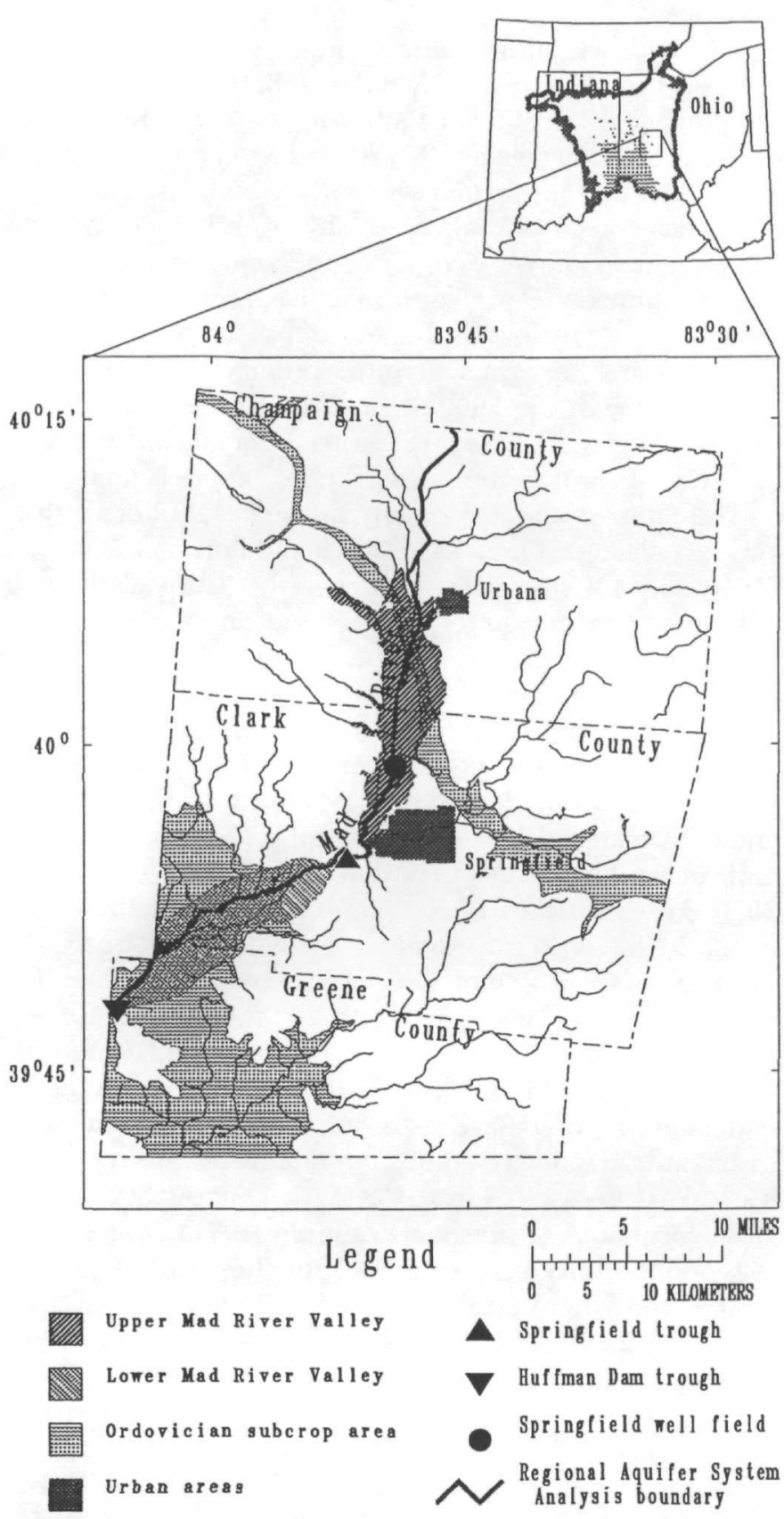

Figure 1. Map showing locations of study area, upper and lower Mad River Valley, Ordovician subcrop, Springfield and Huffman Dam troughs, and Springfield municipal well field.

and its tributaries, and ground-water and surface-water chemistry are used to investigate the amount of carbonatederived ground water entering the valley. Conclusions in this paper are applicable to similar areas in the regional Silurian and Devonian carbonate aquifer system, and the approach described herein can be used to define regional ground-water-flow regimes and boundary conditions of valley-fill/bedrock aquifer systems.

\section{MATERIALS AND METHODS}

\section{Site Description}

The study area referred to in this paper is in southwestern Ohio and consists of Clark and Champaign counties and northern Greene County, an area of approximately $1,000 \mathrm{mi}^{2}\left(2,600 \mathrm{~km}^{2}\right)$ (Fig. 1). Two major cities are in the study area: Urbana in the north-central part and Springfield in the south-central part. The Mad River Valley dissects the study area from north to southwest. This alluvial valley aquifer consists of two parts, a lower and an upper valley, separated by a constriction of the valley, hereafter referred to as the Springfield trough. The Springfield trough is just southwest of Springfield, $\mathrm{OH}$ (Figs. 1,2).

Another constriction of the Mad River Valley is in the southwestern part of the study area, at Huffman Dam (Figs. 1,2). This constriction is hereafter referred to as the Huffman Dam trough. The city of Springfield, OH, relies totally on unconsolidated deposits in the upper valley for its water supply. The Springfield municipal well field is just north of the city, along the Mad River (Fig. 1). Surface topography in most of the study area is generally rolling, with elevations ranging from about $1,300 \mathrm{ft}$ ( 400 m) above sea level in the northeastern part of the study area, to about $850 \mathrm{ft}(260 \mathrm{~m})$ in the lower Mad River Valley. In contrast, land-surface relief is minimal within the upper and lower Mad River Valley.

\section{Data Collection}

A literature search was conducted to ascertain geologic, hydrologic, and geochemical conditions in the study area. The literature search was used, along with water-well logs (data supplied from Ohio Department of Natural Resources, Division of Water), to select appropriate locations for water-level measurements. Water levels in 80 selected bedrock wells were measured to map a potentiometric surface of the Silurian-Devonian carbonate aquifer. Discharge measurements were made at 60 sites along the Mad River and its tributaries, from Urbana to Dayton, OH (Shindel et al. 1992). At several sites, flow was insufficient to measure by use of a flow meter, and discharges were estimated. A water budget for the area was prepared by analysis of hydraulic gradients, streamflow, pumping, and effluent discharges.

\section{RESULTS \\ Distribution and Water-Bearing Properties of Aquifers}

Structurally, the area is controlled by the Cincinnati and Findlay Arch complex, a broad, northward-plunging anticline that trends north-south through the western part of the study area. Consequently, the bedrock in the study area dips slightly (approximately $15 \mathrm{ft} / \mathrm{mi}[2.8 \mathrm{~m} / \mathrm{km}]$ ) to the east away from the axis of the anticline (A. J. Feulner, Ground-water resources of Champaign County, Ohio, Ohio Dept. of Nat. Res. Div. of Water, unpubl. 1959). Ground- and end-moraine deposits cover most of the study area, except in the Mad River Valley, which is filled primarily with glacial outwash deposits. The Silurian and Devonian carbonate aquifer underlies unconsolidated deposits in the northern part of the study area, whereas Ordovician shales and limestones underlie the southern part of the study area (Fig. 1). The subcrop boundary of the Silurian and Devonian carbonate aquifer and relatively impermeable Ordovician shales and limestones passes through the Springfield trough (Figs. 1,2). 

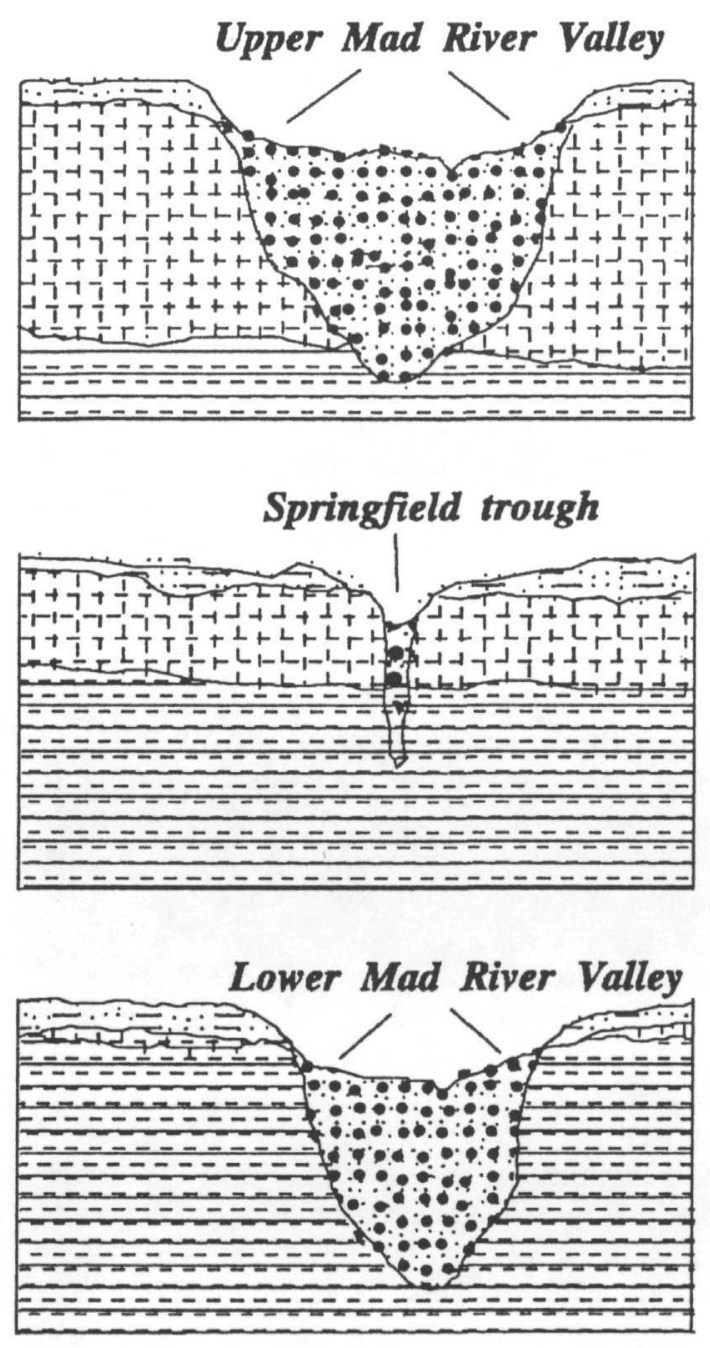

Huffiman Dam trough

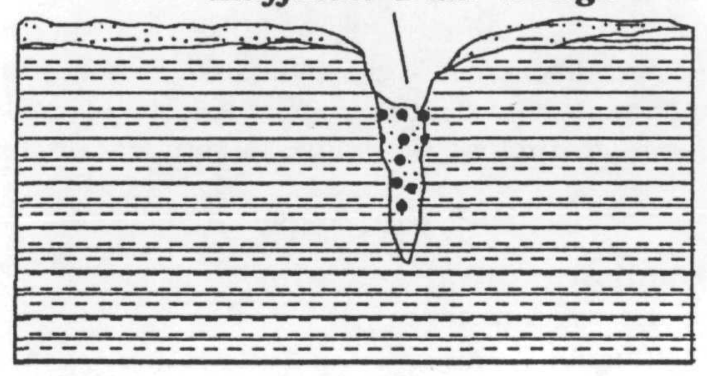

\section{Legend}

Valley-fill deposits (sands and gravels)

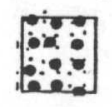

Ground- and endmoraine deposits (till) 풀

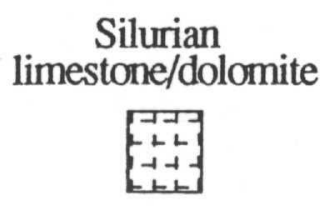

Ordovician
shale/limestone

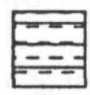

FigURE 2. Generalized geologic sections through the upper Mad River Valley, Springfield trough, lower Mad River Valley, and Huffman Dam trough.

\section{Bedrock}

The bedrock surface underlying the unconsolidated deposits (Fig. 3) is generally flat to rolling, except where the preglacial Teays River Valley, formerly the Kanawha or Teays-Mahomet Valley (Norris and Spicer 1958; Coffey 1958, 1961), and its tributaries incised the bedrock. The bedrock units consist of Ordovician shales and limestones in the extreme southwest corner of the study area (Fig. 1). Silurian limestone and dolomite bedrock typically is present beneath unconsolidated deposits in the rest of the study area, except where the preglacial Teays River eroded through the Silurian bedrock to the Ordovician (Fig. 3). (Fig. 4 shows subdivisions, general thicknesses, and water-bearing properties of these bedrock units.)

The Silurian and Devonian carbonate aquifer of the area is, unlike the Ordovician shales and limestones, relied on heavily for domestic water supply. Transmissivities determined from aquifer tests in the Silurian and Devonian carbonate aquifer in and around the study area range from 70 to $28,000 \mathrm{ft}^{2} /$ day $\left(6.50-2,600 \mathrm{~m}^{2} /\right.$ day) (R. L. Joseph, U.S. Geological Survey, written commun. 1992). On the basis of these aquifer-test data, Casey (1992) derived horizontal hydraulic conductivities for the Silurian and Devonian carbonate aquifer in the Midwestern Basin and Arches RASA study area that ranged from $10^{-2}$ to $5 \mathrm{x}$ $10^{2} \mathrm{ft} /$ day $\left(3 \times 10^{-3}\right.$ to $1.5 \times 10^{2} \mathrm{~m} /$ day $)$. Vertical and horizontal hydraulic conductivities, calculated from analyses of core samples of the Ordovician bedrock in southwestern Ohio range from $10^{-5}$ to $10^{-7} \mathrm{ft} /$ day $\left(3 \times 10^{-6}\right.$ to $3 \times 10^{-9} \mathrm{~m} /$ day) (Casey 1992). Slug tests performed at wells completed in the Ordovician bedrock near WrightPatterson Air Force Base just south of the study area indicate that horizontal hydraulic conductivities are typically less than $1 \mathrm{ft} /$ day $(0.3 \mathrm{~m} /$ day) (D. H. Dumouchelle, U.S. Geological Survey, personal commun. 1991). Water-well logs for the Ordovician bedrock in the study area are scarce, and where available, most indicate yields of less than $2 \mathrm{gal} / \mathrm{min}$ ( 0.1 liter/sec) - much less than yields from the Silurian and Devonian carbonate aquifer to the north.

Water levels from 80 wells, completed at various depths in the Silurian and Devonian carbonate aquifer, were measured in March 1991 and can generally be considered representative of the Silurian and Devonian carbonate aquifer in the study area. A potentiometricsurface map of the Silurian and Devonian carbonate aquifer (Fig. 5), which accounts for topographic variations and surface-water divides, shows that ground water flows generally from uplands toward the Mad River Valley. Near the boundary of Silurian and Ordovician bedrock, in the southern part of the study area, the potentiometric contours indicate that ground-water flow is from the Silurian and Devonian carbonate aquifer toward the Silurian and Ordovician boundary. A series of springs developed along the Silurian and Ordovician subcrop boundary, probably because of the relative impermeability of the Ordovician shales and limestones. At a local scale, the springs and seeps are probably important as local ground-water discharge points in the Silurian and Devonian carbonate aquifer. Water derived from the springs or seeps then becomes surface-water flow or infiltrates back into the unconsolidated deposits as ground water. 


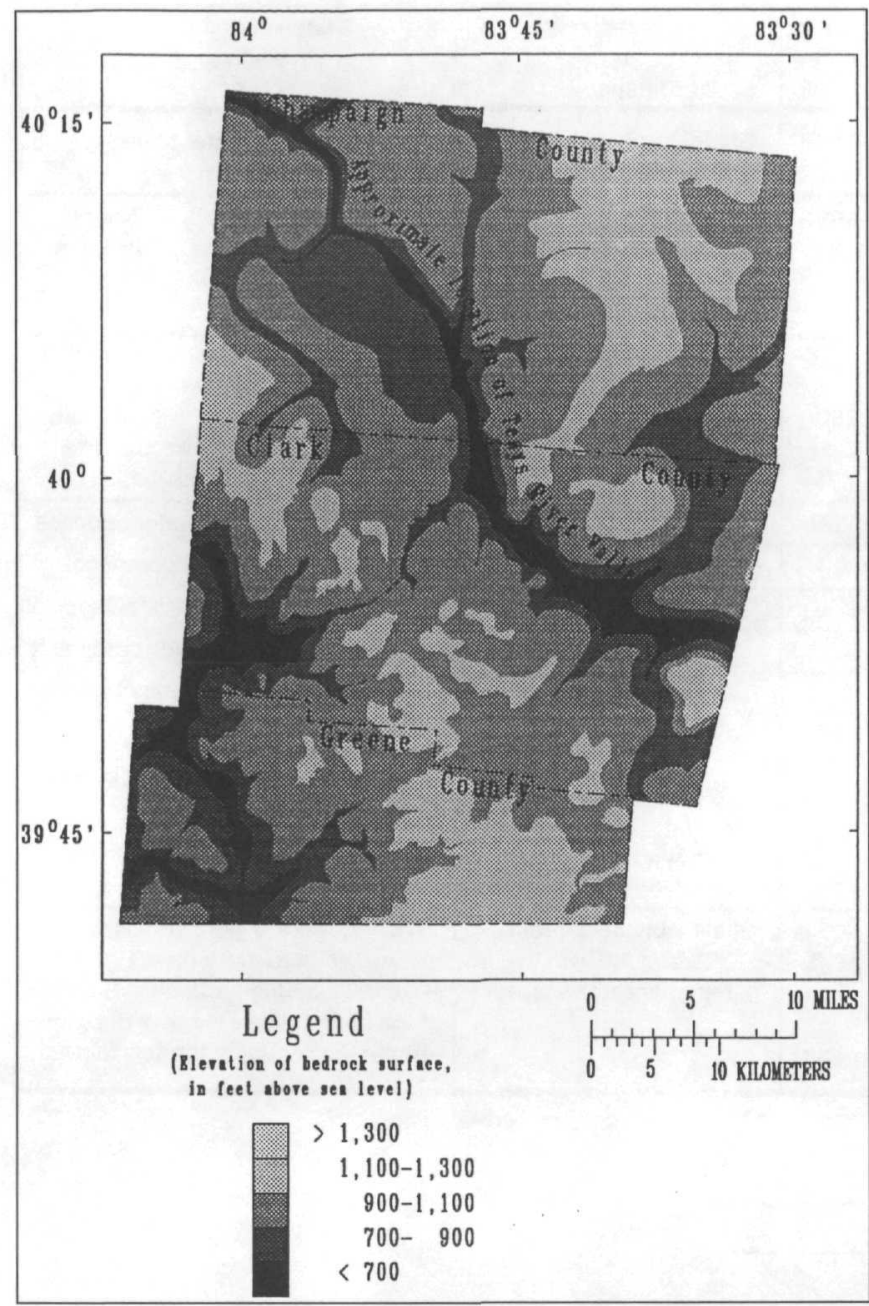

FIGURE 3. Map of study area showing relief on the top of bedrock (bedrock topography). The approximate location of the Teays River Valley is also shown. Modified from Feulner (Ground-water resources of Champaign County, Ohio, Ohio Dept. of Nat. Res. Div. of Water, unpubl. 1959), Leow (Bedrock Topography of Greene County, Ohio, Ohio Dept. of Nat. Res. Geol. Surv. scale 1:62,500, unpubl. map. 1986), Norris et al. (1952).

The potentiometric surface for March 1991 does not differ substantially from a potentiometric surface derived from a survey of drillers' water-level records. Historic records of water levels in the area also indicate that seasonal ground-water level fluctuations range from 3 to $5 \mathrm{ft}(0.9-1.5 \mathrm{~m})$ (Ohio Department of Natural Resources 1970). An accounting of industrial and public water supplies within the study area indicates that nearly all water use from the Silurian and Devonian carbonate aquifer consists of farm and domestic withdrawals.

\section{Unconsolidated Deposits}

Ground moraine, consisting primarily of till, is the most widespread of the unconsolidated deposits in the study area. The till is composed mostly of an unstratified aggregate of clay and rock fragments of various sizes, but sand and gravel lenses are present within the till throughout the study area. End moraines, deposited during the retreat of a Wisconsin-age continental glacier (Norris et al. 1952), generally consist of the same types of materials as does the ground moraine. Thickness of morainic deposits typically is 50 to $100 \mathrm{ft}(15-30 \mathrm{~m})$. Domestic wells completed in the moraines rarely produce more than $5 \mathrm{gal} / \mathrm{min}$ ( 0.3 liter/sec), and most production is from sand and gravel lenses within the till.

Outwash deposits in the study area were deposited by meltwater from the retreating glaciers and generally are stratified sands and gravels within outwash-plain or valley-train deposits. Outwash-plain deposits are not laterally bounded by sides of valleys, and commonly were left as terraces or elevated plains, whereas valley-train deposits are bounded by valley walls. Valley-train deposits provide large amounts of ground water in this area, and their coefficients of permeability range from 1,000 to 5,500 (gal/day) $/ \mathrm{ft}^{2}(0.047$ to $0.26 \mathrm{~cm} / \mathrm{sec})$ (Norris and Spieker 1966, Norris and Eagon 1971). This range of values is approximately equivalent to horizontal hydraulic conductivities of 130 to $740 \mathrm{ft} /$ day ( 40 to $230 \mathrm{~m} /$ day). The Mad River Valley, which trends north-south through the study area, is filled with mainly valley-train deposits, as are many other valleys in southwestern Ohio that cross the Silurian and Ordovician subcrop boundary

The Teays River Valley in this area is partially filled with the so-called Minford Silt, a group of unconsolidated clays and silts thought to be of lacustrine origin and apparently formed by damming of the Teays River by an early Pleistocene glacier (Stout and Schaaf 1931; Norris and Spicer 1958). The Minford Silt is not present as a surficial deposit in the study area; this deposit is restricted primarily to the Teays River Valley, which incises the Ordovician shales and limestones. Drilling records show that the top of the Minford Silt is approximately at an elevation of $860 \mathrm{ft}(260 \mathrm{~m})$ throughout the study area. Drilling records in the area where the Minford Silt is present indicate that wells completed in the Minford Silt produce little ground water. Laboratory analyses of the Minford Silt indicated coefficients of permeability parallel and transverse to bedding planes of 0.0007 and 0.0003 (gal/day) $/ \mathrm{ft}^{2}\left(3 \times 10^{-8}\right.$ and $1 \times 10^{-8} \mathrm{~cm} / \mathrm{sec}$ ), respectively (A. J. Feulner, Ground-water resources of Champaign County, Ohio, Ohio Dept. of Nat. Res. Div. of Water, unpubl. 1959). These values approximately correspond to horizontal hydraulic conductivities of $9 \times 10^{-6}$ and $4 \times 10^{-6} \mathrm{ft} /$ day ( $3 \times 10^{-6}$ and $1 \times 10^{-6} \mathrm{~m} /$ day), respectively, parallel and transverse to bedding planes. The Teays River Valley is not completely filled with the low-permeability materials; rather, the upper $200-300 \mathrm{ft}(60-90 \mathrm{~m})$ is typically filled with till interbedded with sands and gravels. Northwest of the study area, the Minford Silt was entirely eroded and replaced by morainic and/or outwash deposits, produced by glacial scouring of the Teays River Valley. Just north of Springfield, valley-train deposits have replaced the Minford Silt as a result of superposition by the Mad River Valley.

\section{Characteristics of Streamflow}

The Mad River, which flows southward over the central part of the Mad River Valley, has the highest sustained dry-weather flow in Ohio (Cross and Feulner 1964). Generally, the computed percentage of ground-water contribution, or base flow, for the Mad River is greater 


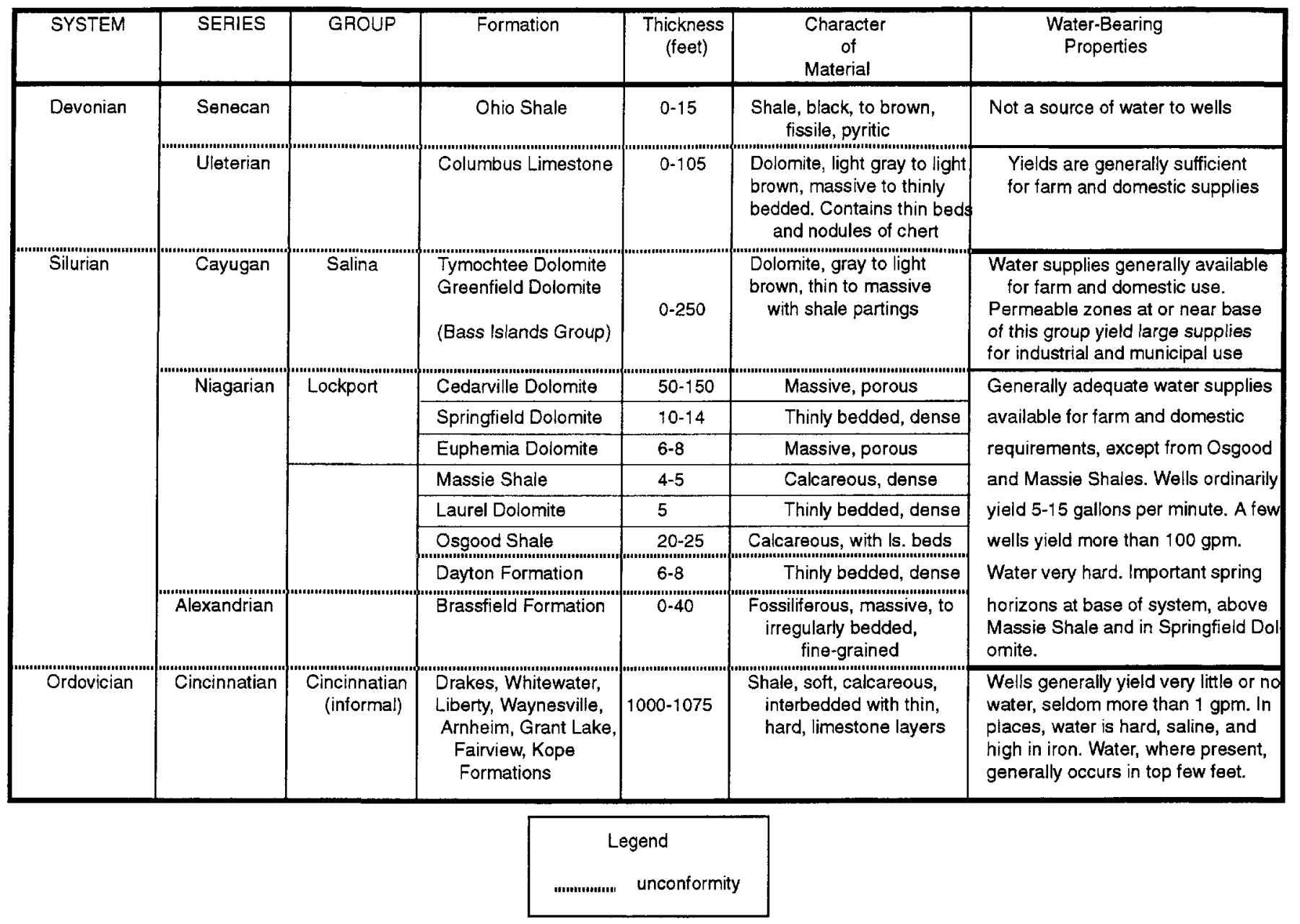

Frcisa: 4. Generalized stratigraphic section in Champaign, Clark, and not them Greene Counties, Ohio. Modified from Hull (1990), Feulner (Groundwater resources of Champaign County, Ohio, Ohio Dept. of Nat. Res. Div. of Water, unpubl. 1959), Norris (1951), Norris et al. (1949, 1952).

than $60 \%$ of the total flow. This base flow is partly caused by the permeable nature of the unconsolidated deposits in the valley (Cross and Hedges 1959) and possibly by considerable discharge from the Silurian and Devonian carbonate aquifer. A low-flow, gain/loss study was conducted on the Mad River and its tributaries from Urbana to just south of the Huffman Dam trough. The cumulative ground-water gain/loss (Fig. 6) was calculated by subtracting the cumulative surface-water inputs to the Mad River from the cumulative change in streamflow in the Mad River downstream from a streamflow-gaging station at Urbana. Data from gain/loss measurements indicate that the Mad River gains flow from ground water at a rate of approximately $4.6 \mathrm{ft}^{3} / \mathrm{sec} / \mathrm{mi}\left(0.08 \mathrm{~m}^{3} / \mathrm{sec} / \mathrm{km}\right)$, from Urbana (river mile 0) to just north of the Springfield municipal well field (river mile 7). For the reach near the Springfield municipal well field (river miles 7-13), the Mad River loses approximately $4.1 \mathrm{ft}^{3} / \mathrm{sec} / \mathrm{mi}\left(0.07 \mathrm{~m}^{3} /\right.$ $\mathrm{sec} / \mathrm{km})$. The Springfield well field was pumping approximately $16 \mathrm{Mgal} /$ day or $25 \mathrm{ft}^{3} / \mathrm{sec}\left(0.71 \mathrm{~m}^{3} / \mathrm{sec}\right)$, when the gain/loss measurements were made (Springfield Water Works, personal commun. 1991). As the Mad River approaches the Springfield trough, the Mad River gains about $13 \mathrm{ft}^{3} / \mathrm{sec} / \mathrm{mi}\left(0.23 \mathrm{~m}^{3} / \mathrm{sec} / \mathrm{km}\right.$ ) (river miles 13-15). Downstream from the Springfield trough (river miles 18-22.5), the Mad River loses approximately $3.1 \mathrm{ft}^{3} /$ $\mathrm{sec} / \mathrm{mi}\left(0.06 \mathrm{~m}^{3} / \mathrm{sec} / \mathrm{km}\right)$ to the unconsolidated deposits of the lower valley. Cross and Feulner (1964) also recognized the same pattern of ground-water gain/loss in this reach of the Mad River. The river then gains about $3.3 \mathrm{ft}^{3 /}$ $\mathrm{sec} / \mathrm{mi}\left(0.06 \mathrm{~m}^{3} / \mathrm{sec} / \mathrm{km}\right)$ until it reaches the Huffman Dam trough (river miles 22.5-31.3). The last discharge measurement of the gain/loss study was severely affected by withdrawals at the city of Dayton's Rohrers' Island well field (just downstream from the Huffman Dam trough) which typically amounts to approximately 50 $\mathrm{Mgal} /$ day or $78 \mathrm{ft}^{3} / \mathrm{sec}\left(2.21 \mathrm{~m}^{3} / \mathrm{sec}\right)$. These measurements compared favorably with a previous gain/loss study on the Mad River and its tributaries (Paulsen 1951), except for the measurement that was affected by ground-water withdrawal.

These data seem to indicate an hourglass effect in the hydrologic system. Ground water derived from the Silurian and Devonian carbonate aquifer and the overlying unconsolidated deposits discharges into the Mad River or into the Springfield municipal well field before it reaches the Springfield trough. As the upper Mad River Valley constricts, forming the Springfield trough, ground water in the unconsolidated deposits is forced to discharge into the Mad River. In the Springfield trough, the 


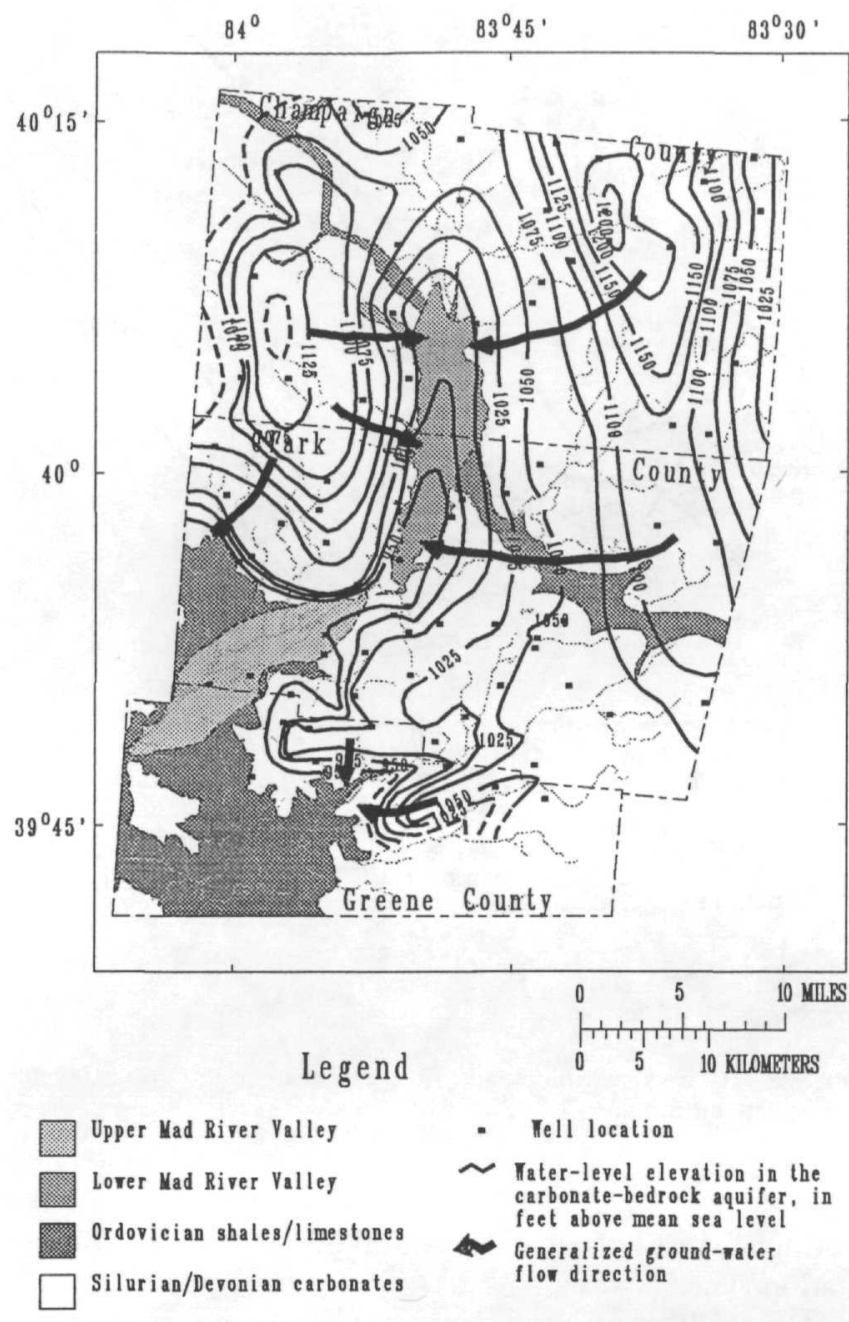

Figure 5. Potentiometric surface of the Silurian and Devonian carbonate aquifer. The positions of the upper and lower Mad River Valleys and the Ordovician subcrop are also shown.

Mad River flows over a possibly thick (about $200 \mathrm{ft}[60 \mathrm{~m}]$ ) sequence of outwash, but the trough is only about $300 \mathrm{ft}$ $(90 \mathrm{~m})$ wide at its narrowest point, so underflow through the outwash is limited. The Mad River loses water into the ground-water system as the lower Mad River Valley widens; the river again comes in contact with the permeable outwash deposits of the lower Mad River Valley. As the lower Mad River Valley narrows into Huffman Dam trough, ground water is again forced to discharge into the Mad River. Underflow through the glacial deposits is again restricted as poorly permeable Ordovician shales bound the valley walls and bottom.

\section{Water Chemistry}

A review of water-quality data for the study area indicates that the water in the Silurian and Devonian carbonate aquifer is generally a calcium magnesium bicarbonate-type water; whereas water from the Ordovician shales and limestones is a sodium chloride type. Ground water derived from the valley-train deposits is typically a calcium bicarbonate type. Major cation/anion chemistry in surface water from the Mad River and its tributaries is similar to that found in water from both the valley-train deposits and from carbonate rocks (Dumouchelle et al. 1993; unpublished data on file at U.S. Geological Survey, Columbus, OH).

Trace elements have previously been used to examine the Silurian and Devonian carbonate aquifer component of surface-water flow in the Mad River. Feulner and Hubble (1960) investigated unusually large strontium concentrations in streams west of the Mad River Valley and north of Springfield. Nettle Creek, an eastwardflowing tributary to the Mad River north of Springfield, typically contains the greatest strontium concentrations, and its location coincides with the buried Teays River Valley. Water from the Silurian and Devonian carbonate aquifer in this area contains relatively large strontium concentrations (9-30 ppm), as a result of the dissolution of the mineral celestite. In their report, Feulner and Hubble (1960) state, ". . . discharge of ground water from the limestone bedrock that flanks the buried valley . . . comes to the surface where Nettle Creek crosses the preglacial channel (the Teays River Valley)." In this case, the Teays River Valley may function locally as a discharge area for the Silurian and Devonian carbonate aquifer. Feulner and Hubble (1960) also state, "When the discharge of the Mad River is below the median, strontium is detectable in the stream." Their results are consistent with the hypothesis that a substantial amount of base
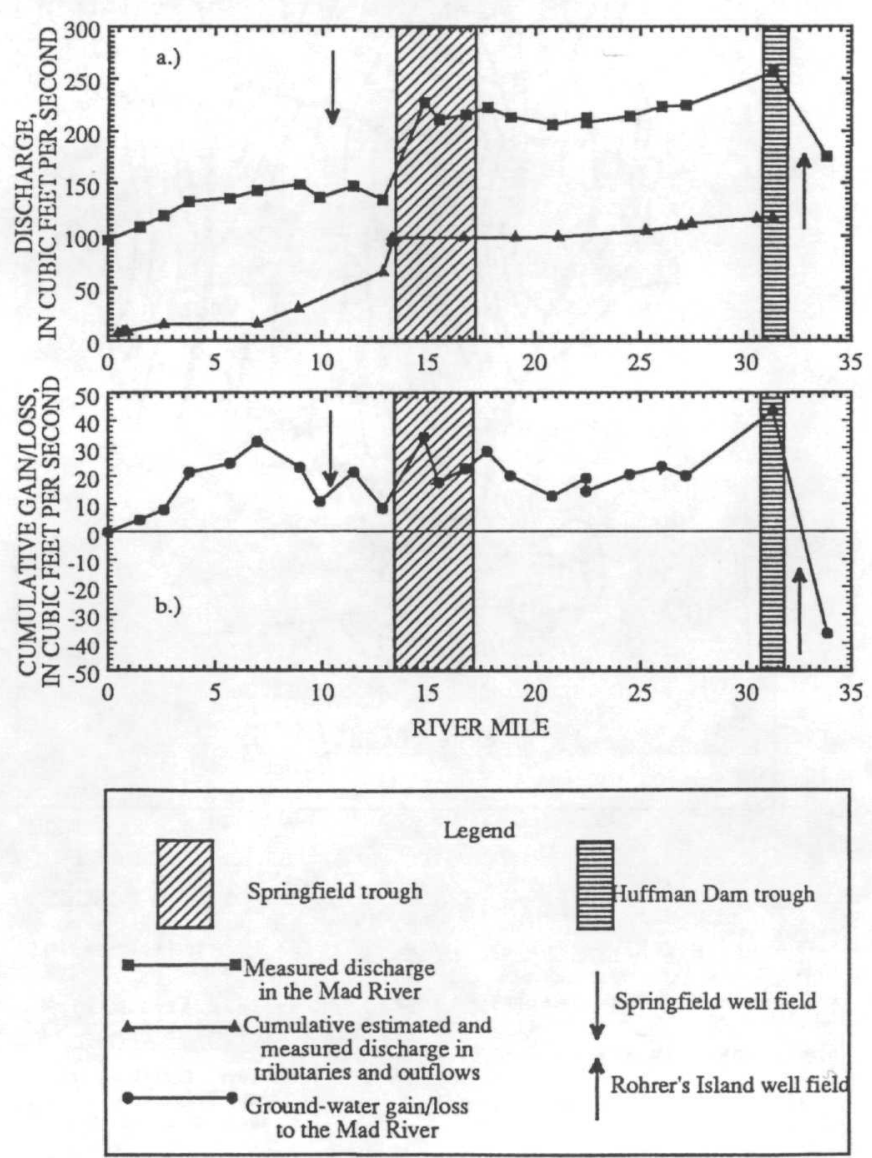

FIGURE 6. Measured discharge of the Mad River (21 July 1991) and cumulative estimated and measured discharge of tributaries and outflows to the Mad River, from the streamflow-gaging station at Urbana (river mile 0 ) to south of Rohrer's Island well field (river mile 34), and groundwater gain/loss to the Mad River. 
flow in the Mad River and its tributaries is ultimately derived from the Silurian and Devonian carbonate aquifer.

\section{DISCUSSION}

\section{Water Budget}

A simplified water budget can be derived for the ground-water drainage basin that includes the Mad River Valley and carbonate-bedrock uplands north of Springfield. On the basis of ground-water-basin divides and flow lines, an area can be outlined that supplies ground water to the Mad River Valley and, ultimately, to the Mad River. The basic assumption for this ground-water drainage basin is that no ground water enters or leaves the basin as underflow. The Ordovician shale, which underlies the Silurian carbonates, is assumed to be impermeable to ground-water flow, and relatively little ground water enters or leaves the basin through unconsolidated deposits. The northern boundary of the area is defined by groundwater flow lines that terminate at the Urbana stream-flowgaging station (Fig. 7). The southern boundaries are defined by ground-water flow lines that terminate in the

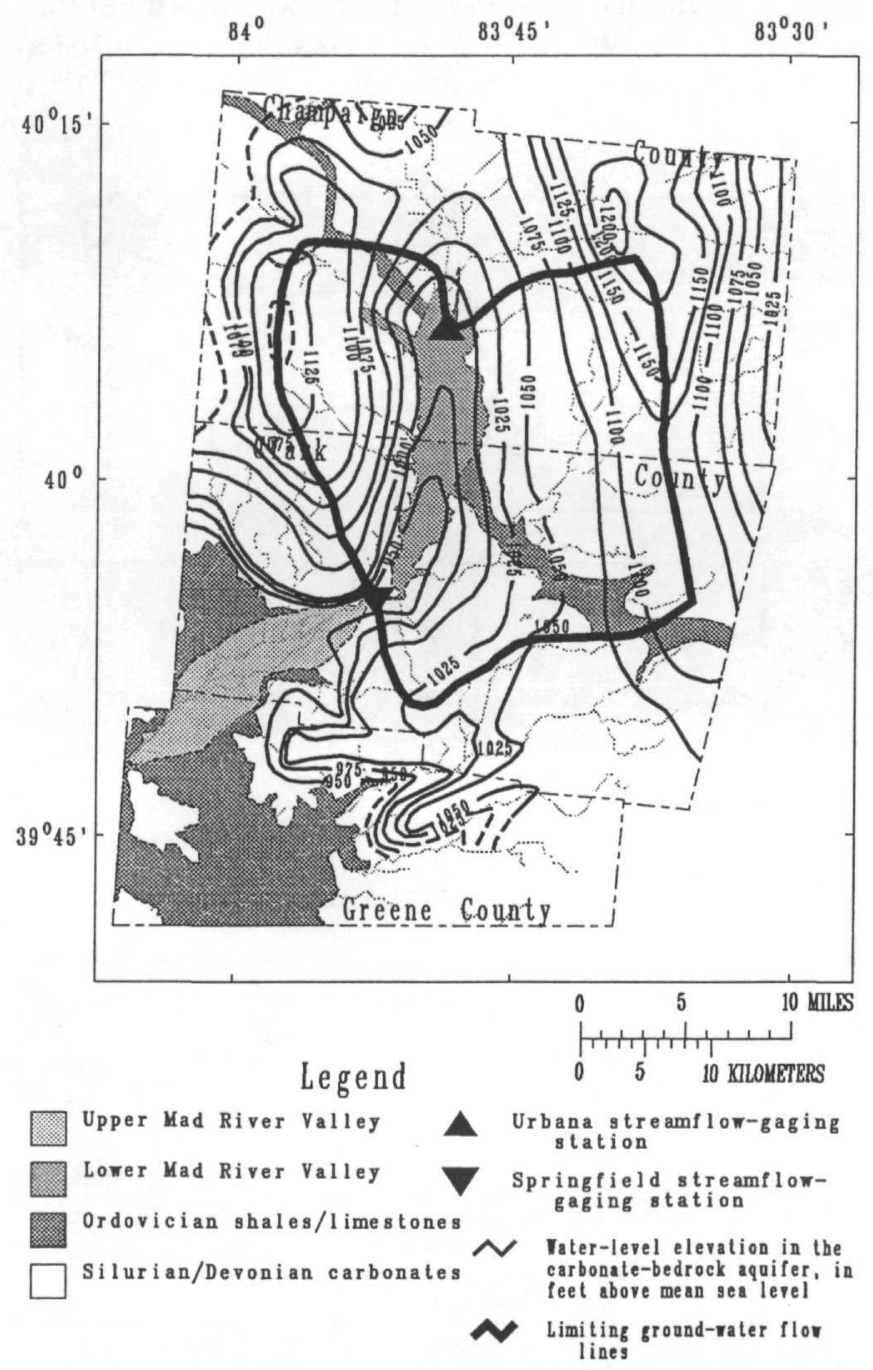

FIGURE 7. Map showing a ground-water basin, as designated by groundwater flow lines and a ground-water divide. The flow boundaries are derived from the potentiometric-surface map of the Silurian and Devonian carbonate aquifer in Fig. 5
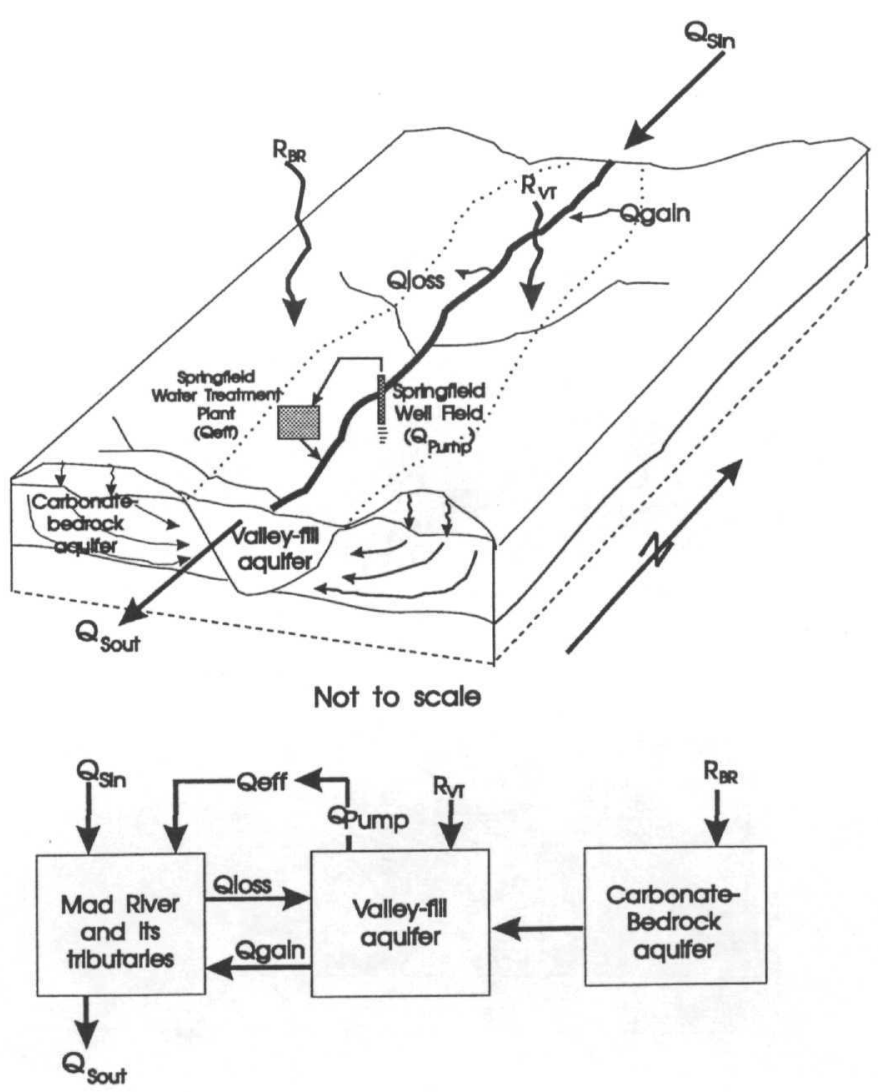

Figure 8. Generalized block and flow diagrams of the ground-water basin, defined in figure 7 .

Springfield trough at the Springfield streamflow gaging station (Fig. 7).

A simplified ground-water/surface-water budget for the system (Fig. 8) can be defined as:

Flow into system $=$ Flow out of system, or;

$$
\mathrm{Q}_{\text {Sin }}+\mathrm{Q}_{\text {eff }}+\mathrm{R}_{\mathrm{vT}}+\mathrm{R}_{\mathrm{BR}}=\mathrm{Q}_{\text {Sout }}+\mathrm{Q}_{\text {Pump }}
$$

where $\mathrm{Q}_{\operatorname{Sin}}$ is stream discharge on the Mad River at the gaging station near Urbana, representing an input to the ground-water drainage basin; $\mathrm{Q}_{\text {eff }}$ is effluent discharge to the Mad River, from the Springfield Sewage Treatment Plant; $\mathrm{R}_{\mathrm{vT}}$ is ground-water recharge in the area underlain by valley-train deposits; $R_{B R}$ is ground-water recharge in the area not underlain by valley-train deposits (that is, predominantly underlain by the Silurian and Devonian carbonate aquifer); $\mathrm{Q}_{\text {Sout }}$ is stream discharge in the Mad River at the gaging station near Springfield, representing flow out of the ground-water-drainage basin; and $Q_{\text {Pump }}$ is average monthly pumping rates in the ground-waterdrainage basin.

Primary inputs to the ground-water/surface-water system are stream discharge at the Urbana streamflow gage, ground water recharge to the valley-train deposits, and ground-water recharge to the remaining area, which is predominately underlain by the Silurian and Devonian carbonate aquifer. Ground-water recharge is defined here as the rate at which infiltration from precipitation reaches the saturated zone. During periods of low flow, as prevailed when the gain/loss study was performed, the 
dominant component of streamflow consists of groundwater discharge; direct runoff within the budget area is negligible. Also, $Q_{\text {sin }}$ includes all of the surface-water inflow to the budget area, given that no tributaries cross the boundaries of the area. The quantity of streamflow attributed to ground-water discharge can be traced back to areal ground-water recharge to the ground-water flow system. Recharge to the ground-water basin was separated into two parts because the ground-water recharge characteristics of the valley-train deposits and the remaining area are assumed to be very different.

Flow out of the system includes ground-water withdrawals from pumping (predominantly from the Springfield municipal well field), and stream discharge at the Springfield gaging station. The ground water pumped from the well field reenters the system as sewage effluent into the Mad River, just upstream from the springfield gaging station. The values for $Q_{\text {eff }}$ and $Q_{P}$ 'ump are approximately equal $\left(Q_{p_{u m p}}-Q_{\text {eff }}=0\right)$, as reported by the Springfield Water Treatment Plant (R. D. Chaffin Jr, Springfield Water Treatment Plant, personal commun. 1992). Other effluent sources to the streams were measured during the gain/loss study by direct measurement or were inferred from temperature and specific conductance measurements of the streams. Most of these effluent sources were traced to ground-water withdrawals from quarries. The difference between quarry groundwater withdrawals and effluent discharge to the streams were considered negligible, as were the effects of evapotranspiration.

The ground-water/surface-water system can be considered closed; that is, no surface water or ground water enters or leaves the system without being accounted for in the budget. Equation (1) can be rewritten and measured rates of discharge from the gain/loss study substituted, as follows:

$$
\begin{aligned}
& R_{\mathrm{vT}}+R_{\mathrm{BR}}=Q_{\text {sout }}-Q_{\text {Sin }} \\
& R_{\mathrm{VT}}+\mathrm{R}_{\mathrm{BR}}=227-95.3=131.7 \mathrm{ft}^{3} / \mathrm{sec}\left(3.73 \mathrm{~m}^{3} / \mathrm{sec}\right)
\end{aligned}
$$

The quantity on the right side of equation (2) represents a gain of flow in the Mad River and tributaries within the ground-water drainage basin. Because all surface sources of water to these streams have been determined, the gain must be from ground-water discharge, which is equivalent to ground-water recharge or $\mathrm{R}_{\mathrm{VT}}+\mathrm{R}_{\mathrm{BR}}$.

Ground-water-recharge rates for the valley-train deposits $\left(\mathrm{R}_{\mathrm{VT}}\right)$ of the lower Mad River Valley have been estimated to be 10 to $15 \mathrm{in} / \mathrm{yr}(25-38 \mathrm{~cm} / \mathrm{yr})$ by a ground-water-level recession-curve technique described by Johansson (1987) (J. T. de Roche, U.S. Geological Survey, personal commun. 1992). Dames and Moore (1971) estimated that groundwater recharge rates to valley-train deposits in a nearby valley were 11 to $21 \mathrm{in} / \mathrm{yr}(28-53 \mathrm{~cm} / \mathrm{yr})$. Multiplying these ground-water recharge rates by the area of the valley converts these recharge rates into ground-water discharge from the valley-train deposits and into units equivalent to stream discharge $\left(\mathrm{L} / \mathrm{T} * \mathrm{~L}^{2}=\mathrm{L}^{3} / \mathrm{T}\right)$.

The only remaining unknown factor in equation (2) is the recharge rate to the area covered with predominantly ground moraine and underlain by the silurian and Devonian carbonate aquifer $\left(\mathrm{R}_{13 R}\right)$. This rate is also the estimated amount of ground water entering the Mad River Valley from the carbonate aquifer (or the unconsolidated deposits overlying the carbonate aquifer) and ultimately discharging into the Mad River during low flow. From equation (2), the range of valley-train recharge rates can be used to calculate the approximate amount of ground-water recharge to the area underlain by Silurian and Devonian carbonates. Ground-water recharge rates of 11 to $21 \mathrm{in} / \mathrm{yr}(28-53 \mathrm{~cm} / \mathrm{yr})\left(\mathrm{R}_{\mathrm{vl}}\right)$ account for the estimated ranges of ground-water recharge for similar areas and materials. The approximate percentage of flow in the Mad River and its tributaries derived from both areas also can be calculated (Table 1 ).

The calculated ground-water recharge rates, $R_{B 3 R}$ (Table 1), are approximate rates that can be expected considering the type of surficial material overlying the Silurian and Devonian carbonate aquifer. These simple assumptions and equations indicate that recharge rates through the ground moraine range from approximately 4 to $6 \mathrm{in} / \mathrm{yr}(10-15 \mathrm{~cm} / \mathrm{yr})$ and that a substantial amount of ground water in the Mad River valley is probably derived from the Silurian and Devonian carbonate aquifer. An estimated 20 to $40 \%$ of the ground-water component of flow in the Mad River is derived from ground-water recharge to the valley-train deposits. The remaining groundwater inflow to the Mad River and its tributaries is probably derived from ground water in the Silurian and Devonian carbonate aquifer. According to these calculations (Table 1), approximately 60 to $80 \%$ of the base flow in the Mad River is ground-water from the Silurian and Devonian carbonate aquifer and/or the overlying morainal deposits.

TABLE 1

Ground-water recharge rates to valley-train deposits $\left(R_{V T}\right)$ and to bedrock $\left(R_{B R}\right)$. Calculated percentages are

\begin{tabular}{|c|c|c|c|c|c|}
\hline \multirow{2}{*}{$\begin{array}{l}\text { Type of } \\
\text { recharge }\end{array}$} & \multicolumn{4}{|c|}{ Recharge rate } & \multirow{2}{*}{$\begin{array}{l}\text { Percent } \\
\text { of total }\end{array}$} \\
\hline & $\mathrm{in} / \mathrm{yr}$ & $\mathrm{cm} / \mathrm{yr}$ & $\mathrm{ft}^{3} / \mathrm{sec}$ & $\mathrm{m}^{3} / \mathrm{sec}$ & \\
\hline Valley Train & 11 & 28 & 27.6 & 0.782 & 21 \\
\hline \multirow[t]{5}{*}{$\left(\mathrm{R}_{\mathrm{VT}}\right)$} & 13 & 33 & 32.7 & 0.926 & 25 \\
\hline & 15 & 38 & 37.7 & 1.07 & 29 \\
\hline & 17 & 43 & 42.7 & 1.21 & 32 \\
\hline & 19 & 48 & 47.7 & 1.35 & 36 \\
\hline & 21 & 53 & 52.8 & 1.50 & 40 \\
\hline Bedrock & 5.7 & 15 & 104 & 2.95 & 79 \\
\hline \multirow[t]{5}{*}{$\left(\mathrm{R}_{\mathrm{BR}}\right)$} & 5.4 & 14 & 99 & 2.80 & 75 \\
\hline & 5.1 & 13 & 94 & 2.66 & 71 \\
\hline & 4.8 & 12 & 89 & 2.52 & 68 \\
\hline & 4.6 & 12 & 84 & 2.38 & 64 \\
\hline & 4.3 & 11 & 79 & 2.24 & 60 \\
\hline
\end{tabular}
of the total estimated ground-water recharge. 


\section{Summary}

Paths of ground-water flow and characteristics of surface-water flow indicate that the Mad River Valley functions as a major discharge area for this part of the regional Silurian and Devonian carbonate aquifer system. In comparison to other alluvial valleys that cross the Silurian carbonate aquifer, the Mad River Valley is unusual in that it has the largest sustained dry-weather flow (base flow) in Ohio. The narrowing of the upper Mad River Valley at the Springfield trough probably contributes to the large base flow, but it also allows investigation of surface-water flow as it relates to ground-water discharge. A water-budget analysis indicates that groundwater recharge rates through the ground moraine in the study area range from 4 to $6 \mathrm{in} / \mathrm{yr}(10-15 \mathrm{~cm} / \mathrm{yr})$. This indicates that a substantial amount of carbonate-bedrockderived ground water flows into the Mad River Valley and mixes with ground water in the valley-train deposits. Ground-water discharge is to the municipal well field north of Springfield and to the Mad River at a rate that increases as the valley constricts at the Springfield trough. Ground water from the Silurian and Devonian carbonate aquifer that has mixed with ground water in the valleytrain deposits of the valleys may constitute 60 to $80 \%$ of surface water during periods of base flow. Previous studies of surface-water and ground-water trace-constituent chemistry support this conclusion.

Valleys that cross the Silurian and Ordovician subcrop boundary seem to play an important role in the groundwater flow regime of the regional Silurian and Devonian carbonate aquifer system. In the past, studies of these valleys did not recognize the potential for the substantial discharge of ground water from the Silurian and Devonian carbonate aquifer system. However, results of this study show that lateral inflow from the Silurian and Devonian carbonate aquifer can be a major factor where the valleys that incise the regional Silurian and Devonian carbonate aquifer system are filled with permeable unconsolidated deposits. Springs and seeps are important local discharge areas along the Silurian and Ordovician subcrop boundary, but the valleys appear to be the predominant discharge areas from the regional Silurian and Devonian carbonate aquifer system in southwestern Ohio.

\section{LITERATURE CITED}

Bugliosi, E. F, 1990 Plan of study for the Ohio-Indiana carbonatebedrock and glacial-aquifer system. U.S. Geol. Surv. Open File Rept. 90-151. $26 \mathrm{pp}$.

Casey, G. D. 1992 Hydrogeology of the basal confining unit of the carbonate aquifer system in the midwestern basins and arches region of Indiana, Ohio, Michigan, and Illinois. U.S. Geol. Surv. Hyd. Atlas 92-W-0433. $1 \mathrm{pl}$.

Coffey, G. N. 1958 Major glacial changes in Ohio. Ohio J. Sci. 58: 43-49.

- 1961 Major preglacial, Nebraskan and Kansan glacial drainages in Ohio, Indiana, and Illinois. Ohio J. Sci. 61: 295-313.

Cross, W. P. and R. E. Hedges 1959 Flow duration of Ohio streams. Ohio Dept. of Nat. Res. Div. of Water. Bull. 31.

and A. J. Feulner 1964 Anomalous streamflow-ground-water regimen in the Mad River basin, near Springfield, Ohio. U.S. Geol. Surv. Prof. Paper 475-D. pp. D198-D201.

Dames and Moore 1971 Ground water resources of selected buried valleys in southwest Ohio. Ohio Dept. of Nat. Res., State of Ohio Summary Rept. Oct. 1971

Dumouchelle, D. H., C. W. Schalk, G. L. Rowe, and J. T. de Roche 1993 Hydrogeology, simulated ground-water flow, and ground-water quality, Wright-Patterson Air Force Base, Ohio. U.S. Geol. Surv. WRIR 93-4047. 214 pp.

Feulner, A. J. and J. H. Hubble 1960 Occurrence of Strontium in the surface and ground waters of Champaign County, Ohio. Econ. Geol. 55: $176-186$.

Fuller, M. L. and F. G. Clapp 1912 The underground water of southwestern Ohio. U.S. Geol. Surv. Water Supply Paper 259.

Harker, D. H. and R. J. Bernhagen 1943 Report on water supply in Preble County. Ohio Water Supply Board.

Hull, D. N. 1990 Generalized column of bedrock units in Ohio. Ohio Dept. of Nat. Res. Geol. Surv. 1 p.

Johansson, P. 1987 Fstimation of groundwater recharge in sandy till with two different methods using groundwater level fluctuations. Journ. of Hyd. 90: 183-189.

Leverett, Frank 1897 The water resources of Indiana and Ohio. U.S. Geol. Surv. 18th Ann. Rept. pt. 4. pp. 419-559.

Norris, S. E. 1951 The bedrock surface and the clistribution of the consolidated rocks in Montgomery, Greene, Clark and Madison Counties, Ohio. Ohio J. Sci. 51: 13-15

W. W. Cross, and R. P. Goldthwait 1947 The water resources of Montgomery County, Ohio. Ohio Water Resources Board. Bull. 12. , W. P. Cross, and R. P. Goldthwait 1949 The water resources of Greene County, Ohio. Ohio Dept. of Nat. Res. Div. of Water. Bull. 19.

, W. P. Cross, R. P. Goldthwait, and E. E. Sanderson 1952 The water resources of Clark County, Ohio. Ohio Dept. of Nat. Res. Div. of Water. Bull, 22.

_ and H. B. Eagon 1971 Recharge characteristics of a watercourse aquifer system at Springfield, Ohio. Groundwater 9: 30-41.

_ and H. C. Spicer 1958 Geological and geophysical study of the preglacial Teays valley in west-central Ohio. U.S. Geol. Surv. Water Supply Paper 1460-E. pp. 199-232.

and A. M. Spieker 1966 Ground-water resources of the Dayton area, Ohio. U.S. Geol. Surv. Water Supply Paper 1808.167 pp.

Ohio Department of Natural Resources Division of Water 1970 Ground water for planning in northwest Ohio-a study of the carbonate rock aquifers. Ohio Water Plan Invent. Rept. 22. 63 pp.

Orton, Edward 1874 Geology of Greene County. Report of the Geological Survey of Ohio, Vol. II. pp. 659-696.

Paulsen, C. G. (ed.) 1951 Low flow investigation, Mad River Basin and adjacent areas, Champaign and Clark Counties, Ohio. Surface Water Supply of the United States, 1948. Part 3: Ohio River Basin. U.S. Geol. Surv. Water-Supply Paper 1113. pp. 353-354.

Shindel, H. L., J. H. Klingler, J. P. Mangus, and L. E. Trimble 1992 water Resources Data-Ohio, 1991, Volume 2, St. Lawrence River Basin Statewide Project Data. U.S. Geol. Surv. Water-Data Rept. OH-91-1. pp. $174-175$.

Stout, W. and D. Schaaf 1931 Minford silts of southern Ohio. Geol. Soc. Am. Bull. 42: 663-672. 